ISSN1027-5495. Functional Materials, 23, No.1 (2016), p. 120-126

\title{
Accelerated wet aging study of flax-reinforced UPR composites
}

\author{
Wang Qiuhong, Ji Yingchao, Wang Ying, Li Hong \\ School of Textile and Material Engineering,Dalian Polytechnic University, \\ Dalian,Liaoning,116034,P.R. China
}

Received 27 July, 2015

\begin{abstract}
The plain and satin fabrics were weaved with 66.67 tex flax yarns. With flax fabric as the reinforcement and Unsaturated Polyester Resin (UPR) as the matrix, composites of two, three and four layers were fabricated respectively by the Vacuum Assisted Resin Infusion (VARI) technique. The wetting capability of the composites was tested firstly. The wetting rate illustrated that the weight of the composites were fast increased when immersed in the water. And the impact property of the composites after saturated in the water for different duration time was tested. The impact property of the four-layer plain fabrics composites was decreased after immersing in water for one-, two-and three-month. After reaching the minimum impact property, the impact property was found recovered after six-month water immersion. For the two- and three-layer plain fabrics specimens, the impact property was increased in the whole experiment process. For the two-layer satin fabrics specimens, the impact property was increased initially for one-month, decreased for two-month and three-month and increased instead for six-month after water immersion. Scanning electron microscopy (SEM) confirmed that the enhancement effect of the wet flax fibre may be over-weighed by the degradation effect of the materials. The results indicated that the materials had experienced some forms of physical damage and/or chemical degradation. The weakening of bonding between fibre and matrix and softening of matrix material were also reasons of the decreased composite property. Keywords: Flax/UPR composites, wet aging, impact property.
\end{abstract}

Получены композиты из двух, трех и четырех слоев обычных и атласных тканей сотканых с льняными нитями 66.67 tex с помощью метода вакуумной инфузии смолы (VARI). Вначале исследовали смачивание композитов. Скорость смачивания показала, что вес композитов увеличивался при погружении в воду. Затем испытали свойства композитов после насыщения в воде в течение различного времени. У четырехслойных обычных тканей свойства снижались после вымачивания в течение 1-3 месяцев. После достижения минимума свойства восстанавливались через 6 месяцев вымачивания. Для двух- и трехслойных обычных тканей свойства возрастали на протяжении всего эксперимента. Для двухслойных атласных тканей возрастание было 1 месяц, 2 месяца - снижение и опять возрастание после 6 месяцев. Сканирующая электронная микроскопия подтвердила, что упрочняющий эффрект влажных льняных волокон может уступать эффекту деградации материала. Результаты показали, что материалы подверглись физическим повреждениям и/или химической деградации. Ослабление связи между волокном и матрицей и размягчение материала матрицы также были причиной снижения свойств композитов.

Дослідження пришвидшеного вологого старіння композитів НПС, зміцнених льоном. Ван Цюхун, Цзи Інчао, Ван Ін, Лі Хун

Отримані композити з двох, три і чотирьох шарів звичайних і атласних тканин сотканых з льняними нитками 66.67 tех методом вакуумної інфрузї смоли (VARI). Спочатку дослідили змочення композитів. Швидкість змочування показала, що вага композитів збільшувалась 
при зануренні у воду. Далі тестували властивості композитів після насичення у воді протягом різного часу. У чотиришарових звичайних тканин властивості знижувались протягом 1-3 місяців. Після досягнення мінімуму властивості відновлювались через 6 місяців вимочування. Для дво- і тришарових звичайних тканин властивості зростали протягом всього експерименту. Для двошарових атласних тканин зростання було 1 місяць, 2 місяці - зниження, і знову зростання після 6 місяців. Сканувальна електронна мікроскопія підтвердила, що зміцнювальний ефект вологих льняних волокон може поступатися ефекту деградації матеріалу. Результати показали, що матеріали зазнали фізичних ушкоджень та/або хімічної деградації. Послаблення зв’язку між волокном та матрицею та розм'якшення матеріалу матриці також спричиняли зниження властивостей композитів.

\section{Introduction}

In recent years environmental problem has become one of the major concerns about the composite research. The high performance synthetic fibres such as glass, aramid, nylon and carbon are expensive and non-renewable although they are used extensively for the reinforcement of plastics. The disposal of the abandoned composite materials has become one sources of environmental pollution when these high performance fibers are involved. Ecomaterials based on renewable resources have attracted growing attention. In many parts of the world, apart from agricultural uses, different parts of the plants have been found to be viable sources of raw materials for industrial purposes [1].Natural fibres, as a relatively new group of environmental friendly materials and a substitute of glass fibre in the composite components, have gained renewed interest in the last decade, by unifying technological, economic and ecological aspects [2,3]. Natural short-fibre reinforced polymeric composites are finding applications in many fields ranging from construction industry to automotive industry. The use of natural short fibre in composites has increased due to their relative cheapness, their ability to recycle and for the fact that they can compete well in terms of strength per weight of material. Over the past decade, cellulose fibres of a fibrous nature have been of great importance, because they can improve the mechanical properties of composites compared to those containing non-fibrous fibres [4-10].

Despite the attractiveness of natural fiber reinforced polymer matrix composites, the disadvantages are moisture absorption leading to fibre swelling and local or seasonal variations in quality that prevent wider use of the composites. The possibility for the outdoor applications makes it necessary to analyze their mechanical behavior under the influence of weathering, which is not a well-studied area. Exequiel Rodriguez et al. have reported that glass fibre composite absorbed ten times less than the jute, sisal and flax composites. Moisture absorption studies of sisal fibre reinforced polypropylene composites have been reported by C. P. L.Chow et al. It has been concluded that the mechanical strength decreased continuously by hot water immersion treatment. Rouison D. et al. studied water absorption of hemp fiber/unsaturated polyester composites and found composite samples immersed in water reached saturation levels after about eight months and showed no signs of cracking due to swelling [11-13].

The flax plant is a member of the Linaceae family which is important for the production of low density fibre. Different varieties of flax are grown in Netherland, Belgium, France and North China. Flax is one of the major natural materials with great potential application in the composite field. Compared with the high performance fibers, such as Kevlar, carbon and glass, the main flax fiber has much higher moisture absorption ability because of its chemical composition and molecular structure. Questions have been raised regarding the property of the flax reinforced materials after long time exposure to high humidity environment. The effect of moisture on the composites is an important matter since such environmental factors are often present in actual service conditions. It is indispensable that the composites retain their mechanical properties with less degradation in the moisture environments [14-17].

It is believed that in the humid environment, water molecules will enter the interface of the composites because of the capillarity [1819]. The polymer matrix and the fibre/matrix interface can be degraded by a hydrolysis reaction of unsaturated groups within the resin [20-23]. Debonding may occur at fibre/matrix interface [24]. A concern with using flax fibre composites in high humidity conditions is the limited understanding and small database of information of their durability.

The aim of this study is to find out the mechanical behavior of the flax/UPR composites after long term water damage and compare the impact property variation of different composites. In this investigation, two-, three- 


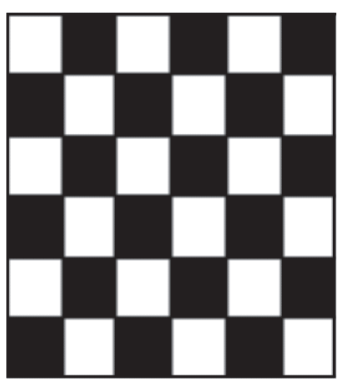

a) Plain

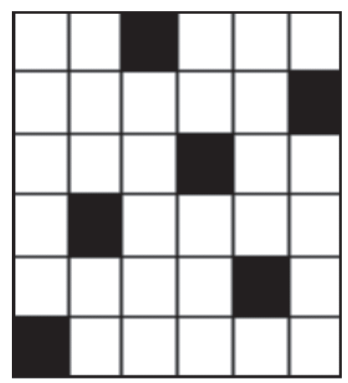

b) Satin
Fig. 1. Fabric structure

and four-layer flax fabrics constructed by plain and satin weave fabricated with unsaturated polyester resin (UPR) by using the vacuum associated resin infusion (VARI) technique firstly. Moreover, the laminates were put into a water tub. After different duration of soaking time, the impact property of the samples was tested. At last, SEM is used to investigate the degradation mechanism of the flax/ UPR composites after immersed in water for certain period of time.

\section{Experimental}

\subsection{Fabrics weaving}

The flax yarns used in the experiments were provided by the Jamusi Textile Company (Heilongjiang province, P. R. China). The yarn fineness was 66.67 tex with the tensile strength of $944.8 \mathrm{cN}$ and elongation at break of $1.48 \%$. The fabric was woven on a rapier loom developed by the Tianjin Polytechnic University. The plain and satin fabrics were weaved with the warp count of 100 ends/ $10 \mathrm{~cm}$ and weft count of 100 picks $/ 10 \mathrm{~cm}$. The plain fabric area weight was $127.95 \mathrm{~g} / \mathrm{m}^{2}$ and thickness $0.59 \mathrm{~mm}$. The satin fabric area weight was $118.68 \mathrm{~g} / \mathrm{m}^{2}$ and thickness $0.75 \mathrm{~mm}$. Figure (1) illustrated the fabric structure.

\subsection{Composites fabricating}

Vacuum Assisted Resin Infusion (VARI) technique was used to fabricate the two-, threeand four-layer laminates, separately with the size of $300 \mathrm{~mm} \times 300 \mathrm{~mm}$. UPR $196 \mathrm{~s}$ was selected as the matrix, which viscosity was 0.22 $0.44 \mathrm{~Pa} \mathrm{~S}$ at $25^{\circ} \mathrm{C}$ and corresponding hardener methyl ethyl ketone peroxide (MEKP) as well as promoter cobalt naphthenate were included in the ingredient. The percentage was $100 \times 1.2 \times 1.5$ in weight. VARI technological process is shown in Fig. (2).
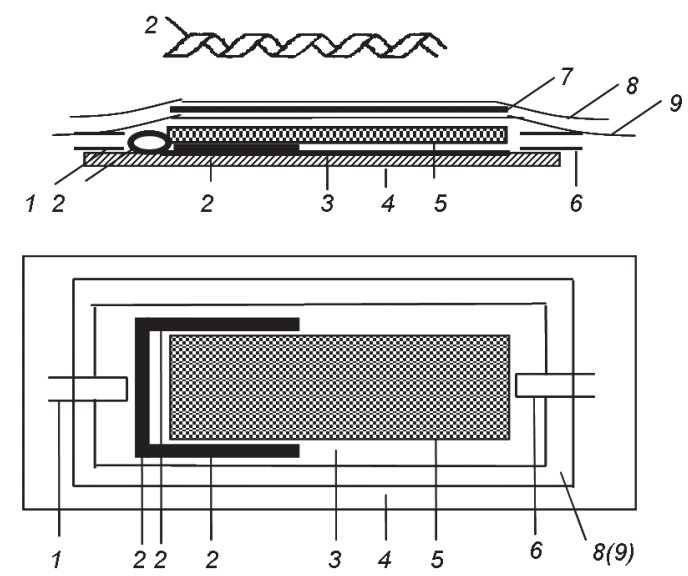

Fig. 2. VARI technological process, where, 1 - resin entrance; 2 - resin distribution (three sections); 3 - skimmed film; 4 - rigid mold; 5 fabric; 6 - air tube (connecting vacuum pump); 7,8,9 - flexible molds.

\subsection{Wetting rate testing of the compos- ites}

According to the GB1034-86, laminates were cut into the size of $20 \mathrm{~mm} \times 20 \mathrm{~mm}$ and immersed in distilled water at room temperature. The specimens were taken out from distilled water, wiped and weighed. The wetting rate was calculated using the following equation:

$$
R=\frac{W_{\mathrm{t}}-W_{0}}{W_{0}} \times 100 \%
$$

where, $R$ - the wetting rate; $W_{0}$ - the composite weight before wetting; $W_{t}-$ the composite weight after wetting.

\subsection{Wet aging of the composites}

According to the HB7401-1996, 48 hours after the fabrication of composites, samples were divided into five groups corresponding to different water immersion periods. In the experiment, five time intervals were used, i.e. 0 , one, two, three and six months respectively. The composite panels were immersed in a large tub containing distilled water. The room temperature during the experiment was within $25 \sim 30{ }^{\circ} \mathrm{C}$. The panels were withdrawn from the water at planned days, wiped dry to remove the water on the surface. After weighed, impact property was tested within 30 minutes after the withdrawal of the samples from the tub.

\subsection{Impact property testing of the com- posites}

Laminates were cut parts of $95 \mathrm{~mm} \times 95 \mathrm{~mm}$ in accordance with ASTM D3763 rules. The impact property was tested with the Universal Impact Tester (INSTRON Dynatup 9250HV, United States). The weight of impact hammer was $5.7806 \mathrm{~kg}$, form was bullet and speed was $2.5 \mathrm{~m} / \mathrm{s}$. For each group of composites, the val- 


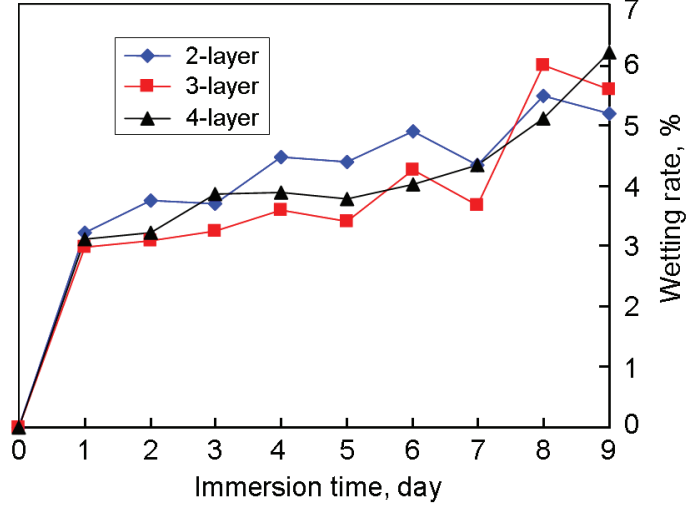

Fig. 3. Wetting rate of composites

ues of the impact property were the arithmetic mean of at least eight specimens.

\subsection{SEM Testing of the Composites}

The broken sections of the flax/ UPR composite before and after the water immersion were investigated by SEM (Quanta-2000, Czech).

\section{Results and Discussion}

\subsection{Wetting capability of the composites}

The wetting rate of different layer composites was shown in Fig. (3).

From Fig. (3), it can been seen that the wetting rate of flax-reinforced UPR composites increased fast during the prime 24 hours, with 2-layer specimens $3.23 \%$, 3-layer $2.98 \%$ and 4-layer $3.11 \%$. From 1- day to 6-day, in spite of the data fluctuating, the total trend of wetting rate curve raises and reached to the maximum, i.e.2-layer $5.19 \%$, 3-layer $5.58 \%$ and 4 layer $6.2 \%$ on 9 -day in this experiment. The reasons were as follows. Firstly, hydroxyl covalent binding occured between water molecules and flax fibre or resin matrix. And at the same time, water molecules arised capillary infiltration along the inter-phase between fibre and resin and the holes in materials. Moreover, the weight of materials decreased owing to water dissolution and degradation. Therefore, it was obvious that the weight changes of the flax-reinforced UPR composites were affected by the two aspects above.

\subsection{Effect of impact property}

The two-, three- and four-layers plain fabrics-reinforced UPR composites and two-layers satin composites were immersed in distilled water for one, two, three and six months respectively. The impact properties were tested and the results were shown in Fig. (4) and Fig. (5).

From Fig. (4) and Fig. (5), it can be seen that the impact property of different composites was different. The impact property of the two-layer

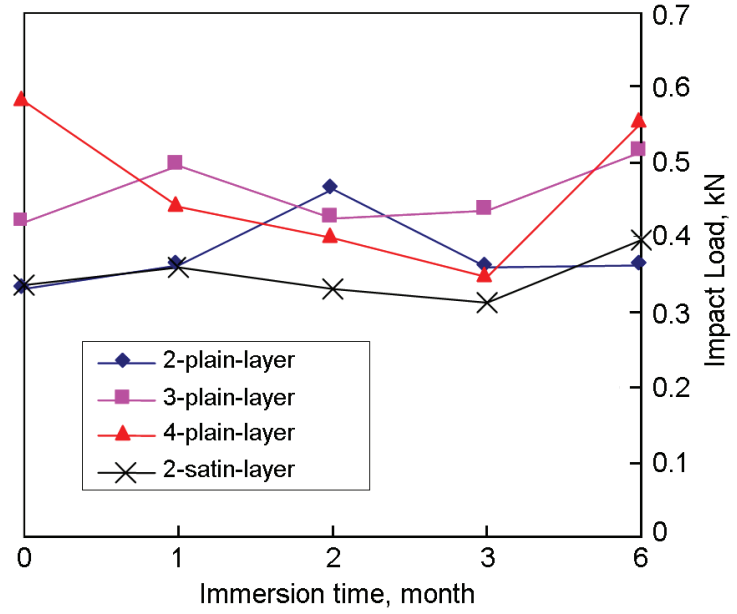

Fig. 4. Impact load of composites

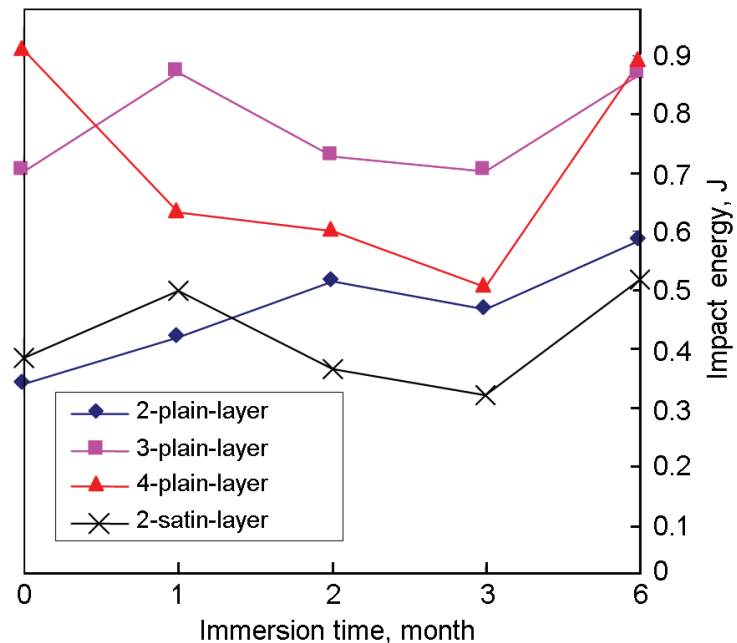

Fig. 5. Impact energy of composites

satin composites was decreased for two- and three-month. The impact property of the fourlayer plain composites for one-, two- and threemonth was decreased obviously but recovered for six-month. From the original specimens, the impact property of the four-layer composites was the best. The decline of the impact property of the composites obtained in this experiment may be a consequence of the different influence effects: the (i) material decomposition; (ii)interfacial debonding; (iii) voids and cracks in the material. When the composites had been immersed in water, water molecules firstly entered the free space of voids and cracks in the composites, at the same time, water molecules could rapidly pass through and diffuse along the interface between the fibre and matrix owing to the capillarity. The inter-facial bond strength had been weakened by the plasticization effect of the absorbed water. On the other hand, water molecules would be attracted by the hydrophilic groups in the flax fibre and the unsatu- 


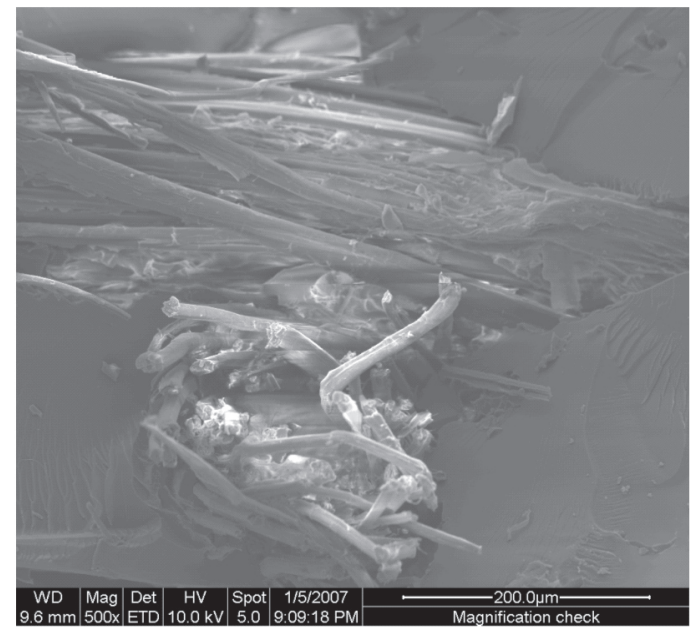

Fig. 6. Original two-layer

rated polyester. After longer time immersion in water, hydrophilic groups of the polyester and the flax fibre would have chemical reactions with water molecules. The result suggested an irreversible process might be the cause of the property deterioration of the materials.

Compared to the original specimens, the impact property of the two-and three-layer plain composites for one-, two-,three-and sixmonth was increased after immersion in water. And the two-layer satin composites for one- and six-month were increased. As was discussed above, the deterioration of the matrix, the reinforcing material as well as the interface was also unavoidable. However, the water may act as a plasticiser to favor the impact property. Compared with the original air molecules trapped in the voids before water immersion, water molecules would be more active in resisting the impact action. Moreover, the specimens tested after the withdrawal from the water were not completely dried, this promoted to the impact property because the wet flax was swelling adequately and wet strength of flax is much larger than its dry strength. Finally, the complex curing and fabricating processes leaded to the consolidation of the composites was incomplete. After longer time immersion in water, the unsaturated polyester may have oxidation reactions with the oxygen in the water, which may lead to an increase of the cross-linking density of the matrix and further enhance the impact property of the composites.

From Fig. (4) and Fig. (5), we can also see that the two-layer plain and satin composites appeared different results. The impact properties of the two-layer plain composites were increased after immersion in the water. Those of the two-layer satin composites was increased for one-month and six-month and decreased

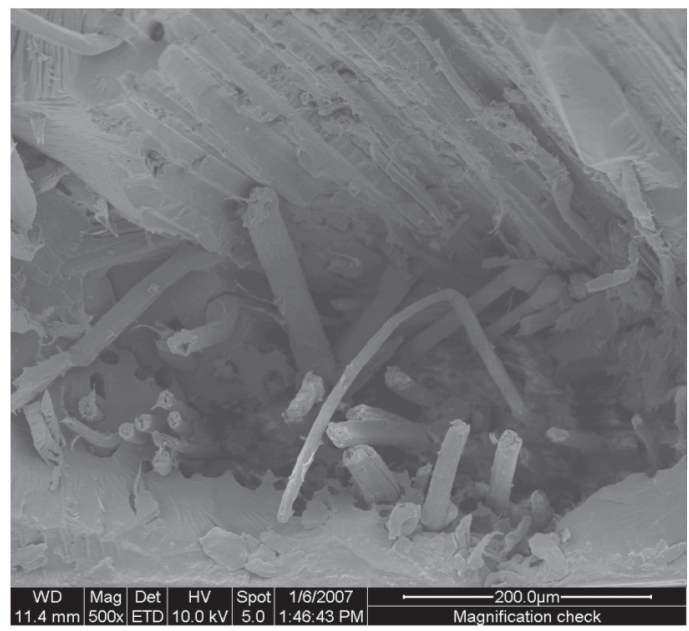

Fig. 7. Two-layer for six-month

for two-month and three -month after immersion in the water. The reason for the difference of impact properties was owing to the fabric structure. The plain was of the most crossing point and the satin was of the longest float. The plain and satin fabric with same warp count and weft count were of different area weight and thickness, the former $127.95 \mathrm{~g} / \mathrm{m}^{2}$ and $0.59 \mathrm{~mm}$ and the latter $118.68 \mathrm{~g} / \mathrm{m}^{2}$ and 0.75 $\mathrm{mm}$, which were the major factors influencing the impact property of composites. The twolayer plain fabrics-reinforced composites were possible of more voids and cracks and poorer interface between fibre and matrix than the satin fabrics-reinforced composites. In other words, the plasticization effected by the water may be contributed to the improvement of the impact properties.

There was one exception of the data in the Fig.4, compared to the other two-layer plain specimens, the impact load of the two-layer plain composites was increased a great deal after two-month soaking in water. The higher standard deviation showed an unsteady trend which might be arisen by the experimental error.

The panel layers and fabric structure may influence the impact property testing results in water durability studies if the duration of the immersing time was relatively short.

\section{Failure mode}

Figure (6) and Figure (7) showed the SEM images taken from the broken sections of the two-layer plain specimens before and after the water immersion respectively. Figure (8) and Figure (9) showed the broken section of the four-layer specimen before and after the water treatment. 


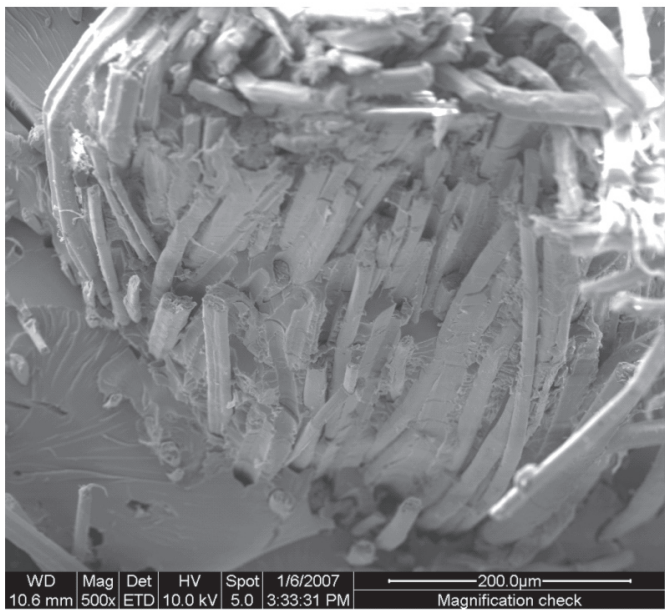

Fig. 8. Original four-layer

From Fig. (6) and Fig. (8) it can be seen that the matrix was closely adhered with the flax fibre bundle. Delamination between the fibre and the matrix can't be detected. During the impact property test, no pull out of the fibres from the matrix was found. All of these results prove that the interface between the flax fibre and the polyester matrix was perfect.

After six-month water immersion, Fig. (7) showed that the flax fibres were still closely been held by the polyester resin, no obvious debonding had been found. The enhancement effect of the wet flax fibre may be overweighed by the degradation effect of the materials.

From Fig. (9), it can be seen that the interface between the flax fibre and the UPR matrix in the four-layer specimen was bare with fewer adhered resin particles. This may illustrate that debonding happened between the fibre and the matrix. During the moisture absorption, water molecules came into the free space of polymers or micro-voids formed by cavities and cracks, which induced more new macro-cavities and cracks with time prolonged, thus the interface was gradually damaged.

The results indicated that the materials had experienced some forms of physical damage and/or chemical degradation. The weakening of bonding between fibre and matrix and softening of matrix material were also reasons of the decreased composite property.

\section{Conclusions}

In this research, flax plain and satin fabrics were used as reinforcement and unsaturated polyester as matrix. The composites of two-, three- and four-layer were fabricated respectively by the VARI technique. The experiment was illustrated that water molecules played a

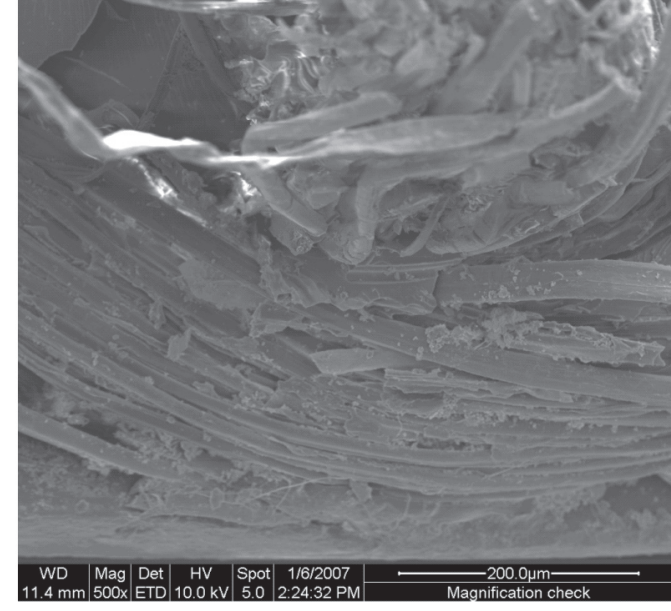

Fig. 9. Four-layer for three-month

significant role influencing the impact property of the composites.

Most of the two- and three-layer plain and the two- satin fabric-reinforced composites had a relatively better water durability by the experimentation. Although the impact energy of two-satin fabric-reinforced composites after immersion was decreased by 5.1\% for two-month and $16.5 \%$ for three-month, it was increased by $34.6 \%$ for six-month. The change of the impact property of four-layer plain composites was more outstanding than others. The impact energy of the laminates after immersion was decreased by $30.5 \%$ for one-month, 33.8 $\%$ for two-month, $44.5 \%$ for three-month and $2.0 \%$ for six-month. The reason might be that the water immersion aging affected the microstructural integrity of the laminated plates causing numerous defects.

For the flax fabric composite aimed as impact property in the humid environment, it was not beneficial if the layer of material was added in this experiment. It could be illustrated by the reduced impact energy of the four-layer composites resulted from the deteriorated fibre, matrix and interface. The maximum decrease rate of the impact property was $44.5 \%$. For the four-layer laminates employed in the research, the chemical reaction of the water molecules with the fibre and the matrix and the delamination damage caused by the penetration of the moisture into the materials would be faster and earlier.

For the material with suitable layers, the serrate change of the impact property revealed that there were conflict effects in the material. When the composites were immersed in water, the voids and cracks in the material would be gradually filled with water molecules, and the capillarity effect would encourage the water 
penetration. With time prolonged, it was understood that chemical reactions would happen between the water molecules and the flax fibre as well as the matrix. This would damage the impact property of the laminates. On the other hand, the water molecules were considered responsible for the increase of the impact property with longer time water immersion. The material was more even than the original penal because of the filled voids and cracks by the water molecules and the fibre and matrix would be bonded with the hydroxyl group of the water, this would resist the damage during the impact testing. At the same time, the water might work as a plasticizer for flax fibre to resist the impact action resulting an increased impact property. So the moisture durability of the composites may be improved by the application of the flax fibre.

Therefore moisture absorption should be taken into consideration when flax fibre was employed as the reinforcement in the composites because of its hydrophilic nature in order to obtain reliable composite materials.

\section{Acknowledgements}

This work supported by Fund of Project of Education Department of Liaoning Province, China (No.2006B013). Liaoning province colleges' outstanding talent support program (No. LJQ2015008).

\section{References}

1. S. G, B. J and R. H. J.Thermopl. Comp. Mater, 9, 239, 1996.

2. M. A. Khan, M. M. Hassan, L. T. Drzal. Compos. Part A: Appl. Scie. Manufact.,1, 71, 2005.

3. K. Oksman,M. Skrifvars, J. F. Selin. Compos. Scie.Techn., 7, . 1317., 2003.

4. A. K. Bledzki, W. Zhang, A. Chate.Compos.. Sci. Techn., 61, 2405, 2001.
5. M. M. Thwea, K. Liao. Compos. Sci. Techn., 63, 375, 2003.

6. C.Z. Paiva Junior, L.H. de Carvalho, V.M. Fonseca et al. Polymer Test, 23, 131, 2004.

7. T.A. Bullions, D. Hoffman, R.A. Gillespie et al. ,Comp Sci Techn, 66, 102, 2006.

8. M. L. Bras, S. Duquesne, M. Fois et al. Polym. Degrad.Stabi.,88, 80, 2005.

9. E. Baysal, M. K. Yalinkilic, M. Altinok et al. Constr. Build. Mater., 21,1879, 2007.

10. M. J. John, S. Thomas. Carbm. Polym., 71, 343, 2008.

11. E. Rodriguez, R. Petrucci, D. Puglia et al. , J. Comp. Mater., 39, 265, 2005.

12. C.P.L.Chow, X.S.Xing, R.K.Y.Li. Comp. Scie. Techn, 67, 306, 2007.

13. Rouison D., Couturier M., Sain M. et al., Polym. Comp., 26, 509, 2005.

14. E. Bodros, I. Pillin, N. Montrelay et al. Compos. Scie. Techn., 67, 462, 2007.

15. X. Huang, A. Netravali, Comp. Scie. Techn., 67, 2005, 2007.

16. M. Baiardo, E. Zini, M. "Scandola, Comp. Part A: Appl. Scie. Manufact., 6, 703, 2004.

17. T. Kawaguchi, R. A. Pearson, Comp. Scie. Techn. 64,1991, 2004.

18. Zhang Jihua, Zhan Maosheng, J.Comp. Mater., 38, 779, 2004.

19. N.Godin, S.Huguet, R.Gaertner., Comp. Struct., 72, 79, 2006.

20. A. Kootsooks, A. P. Mouritz, Comp.Scie.Techn, 64, 1503, 2004.

21. C. Suri, H. Hamada, K. Koyama, Adv.Comp. Mater., 10, 63, 2001.

22. A. Hodzic, J.K. Kim, A. E. Lowe et al. , Comp Scie. Techn., 64, 2185, 2004.

23. V. A. Alvarez, A. Vazquez, J.Comp. Mater., 38, 1165, 2004.

24. K. Imielinska, L. Guillaumat, Comp. Scie.Techn., 64, 2271, 2004. 